\title{
Enhancement of High Threshold Calcium Currents in Rat Primary Afferent Neurons by Constitutively Active Protein Kinase C
}

\author{
Karen E. Hall, ${ }^{1}$ Michael D. Browning, ${ }^{3}$ Ellen M. Dudek, ${ }^{3}$ and Robert L. Macdonald ${ }^{2}$ \\ Departments of ${ }^{1}$ Internal Medicine and ${ }^{2}$ Neurology, University of Michigan, Ann Arbor, Michigan 48109 and \\ ${ }^{3}$ Department of Pharmacology, University of Colorado Health Sciences Center, Denver, Colorado 80262
}

Protein kinase $\mathrm{C}$ has been implicated in the modulation of calcium channel function. However, controversy exists concerning the actions of agents such as phorbol esters or diacylglycerol (DAG) that activate endogenous PKC, with both enhancement and inhibition of $\mathrm{Ca}^{2+}$ currents described. In this article we report the effects of direct intracellular application of a constitutively active form of PKC (PKM) on whole cell calcium currents in acutely dissociated rat dorsal root ganglion neurons. PKM application significantly enhanced high threshold voltage-activated calcium currents elicited from holding potentials of $-80 \mathrm{mV}$ and $-\mathbf{4 0} \mathrm{mV}$. The rate of current rundown in PKM-treated cells was not significantly different from controls. The enhancement observed with PKM was not due to a shift in the voltage dependence of the peak current. Synthetic PKC inhibitor peptide (PKC-I) added to recording solutions containing PKM (PKM+PKC-I) abolished the PKM-associated enhancement. The rate of current rundown was significantly increased in the presence of PKM+PKC-I, and PKC-I alone, suggesting that substantial enhancement of voltageactivated calcium currents by endogenous PKC occured in this preparation of rat dorsal root ganglion neurons. The portions of current attributable to N-, L-, and non-N,L-type currents [determined by applying the $\mathrm{N}$ - and L-type calcium antagonists $\omega$-conotoxin GVIA and nifedipine (3-10 $\mu \mathrm{M})]$ were not affected by PKM, suggesting that both $N$ and $L$ current components were enhanced by PKM. In addition, in the presence of both blockers, significant enhancement by PKM of a current resistant to both nifedipine and $\omega$-conotoxin was observed, suggesting that PKM enhanced additional high threshold voltage-activated calcium currents.

[Key words: protein kinase $C$, calcium currents, dorsal root ganglia, second messengers, calcium channels, rat]

Activation of voltage-gated calcium channels in the cell membrane leads to a cascade of intracellular events including: synaptic transmitter release, secretion, release of calcium from intracellular pools and activation of other ion channels. One im-

\footnotetext{
Received Apr. 15, 1994; revised Apr. 28, 1995; accepted May 2, 1995

We thank Nadia Esmaeil and Samir Suleiman for their excellent technical assistance. This work was supported by a Medical Council of Canada Centennial Fellowship awarded to K.E.H.; National Institutes of Health Grants AG04418, AA03527, AA09615 awarded to M.D.B.; and National Institutes of Drug Abuse Grant DA04122 awarded to R.L.M

Correspondence should be addressed to Dr. Robert L. Macdonald, University of Michigan, Neuroscience Building, Room 1100, 1103 East Huron Street, Ann Arbor, MI 48104-1687

Copyright 1995 Society for Neuroscience $0270-6474 / 95 / 156069-08 \$ 05.00 / 0$
}

portant mechanism regulating ion channel function is phosphorylation by $\mathrm{Ca}^{2+} /$ phospholipid-dependent protein kinase C (PKC) (Chang et al., 1991). Much of the published data concerning the effects of PKC on neuronal calcium channel function has been obtained using activators of endogenous PKC, such as diacylglycerol or phorbol esters (Swartz, 1993; Yang and Tsien, 1993). The effects of phorbol esters on voltage-activated calcium channel function are somewhat controversial, with both decreased and increased $\mathrm{Ca}^{2+}$ currents reported (Rane and Dunlap, 1986; Lacerda et al., 1988; Gross and Macdonald, 1989; Madison, 1989; Rane et al., 1989; Boland et al., 1991; O'Dell and Alger, 1991; Swartz, 1993; Swartz et al., 1993; Yang and Tsien, 1993). Several possible explanations for this discrepancy may exist. Phorbol esters are carcinogenic compounds that, in addition to activating endogenous $\mathrm{PKC}$, may also directly inhibit the calcium channel at high concentrations (Hockherger et al., 1989; Doerner et al., 1990). Intrinsic differences among various phorbol esters in their specificity of action on PKC have been described (Liu et al, 1993). Increased calcium currents with acute application of PKC and decreased currents with prolonged contact has been reported (Mathies et al., 1987; Ewald et al., 1988), suggesting that tachyphylaxis occurs with prolonged exposure to PKC activators. Other potential variables include variations between cell types and species in the endogenous baseline PKC levels, the types of PKC isoforms present (Tanaka and Saito, 1992), or the mechanism(s) of PKC action on calcium channels (Alkon and Rasmussen, 1988). An attenuating effect of phorbol esters on PKC levels has been reported (Rodriguez-Pena and Rozengurt, 1984; Wolf et al., 1984). Finally, recruitment of covert or previously inactive calcium channels by PKC has been described in Aplysia neurons (Strong et al., 1987).

Recause the effects of indirect activation of PKC are unclear, we decided to administer a constitutively active form of PKC directly into the cell through the recording pipette, and thus to determine the direct effect of PKC on whole cell calcium currents in acutely dissociated dorsal root ganglion (DRG) neurons.

\section{Materials and Methods}

All animal experimentation was conducted in accordance with the National Institutes of Health Guidelines for the care and use of laboratory animals (NIH Publication 85-23, revised 1985).

Preparation of acutely dissociated neurons. DRG neurons were prepared from 14-21 d old Sprague-Dawley rats of both sexes using a technique similar to that described previously (Gross et al., 1990a). After removal from the spinal column, thoracic DRGs wcre minced, incubated with collagenase and trypsin (Sigma Chemical Co., St. Louis, $\mathrm{MO}$ ), and then triturated to separate the cells. Cells were plated on rat tail collagen-coated culture dishes, in minium essential medium (MEM) (GIBCO, Grand Island, NY) supplemented with $16.5 \mathrm{mM} \mathrm{NaHCO}_{3}, 28.2$ $\mathrm{mm}$ glucose, nerve growth factor $(10 \mathrm{ng} / \mathrm{ml}$; Boehringer-Mannheim, In- 
dianapolis, IN), and $10 \%$ fetal calf serum (GIBCO). Cultures were incubated at $37^{\circ} \mathrm{C}$ in a $93 \%$ air $+7 \% \mathrm{CO}_{2}$ atmosphere, and recordings made at $21^{\circ} \mathrm{C}$, between 1.5 and $7 \mathrm{hr}$ after plating.

Preparation of synthetic catalytic protein kinase $C(P K M)$ and protein kinase $C$ inhibitory peptide (PKC-I). Constitutively active PKC (PKM) was isolated and purified from bovine brain as previously described (Woodgett and Hunter, 1987; Browning et al., 1990). Removal of $\mathrm{Ca}^{2+}$ /phospholipid dependency of PKC was achieved by trypsin treatment (Huang and Huang, 1986). After trypsin treatment, PKM was repurified by soybean trypsin inhibitor affinity column chromatography, concentrated, and dialyzed against a buffer with the following composition: TEA $2 \mathrm{~mm}$, EGTA $5 \mathrm{~mm}, \mathrm{MgCl}_{2} 6 \mathrm{~mm}, \mathrm{KCl} 140 \mathrm{~mm}$, HEPES $10 \mathrm{~mm}, \mathrm{CaCl}_{2} 1 \mathrm{~mm}$, and titrated to $\mathrm{pH} 7.5$ with $\mathrm{KOH}$. Following sequencing, the subunit was synthesized, dissolved in aqueous buffer to a concentration of $5 \mu \mathrm{g} / \mathrm{ml}$ and stored as $2-5 \mathrm{ml}$ aliquots at $-70^{\circ} \mathrm{C}$.

PKC inhibitory peptide (PKC-I) with a sequence identical to amino acids $19-31$ of protein kinase $\mathrm{C}$ was synthesized, dissolved in aqueous buffer to a concentration of $4 \mathrm{mM}$ and stored at $-70^{\circ} \mathrm{C}$.

Preparation of solutions. PKM, PKC inhibitor peptide, and vehicle were stored at $-70^{\circ} \mathrm{C}$ as aliquots of the stock solutions described above. Just before use, working solutions of PKM, PKM+PKC-I, PKC-I alone, and vehicle (control) were prepared. The stock PKM was diluted with internal recording solution (see below) to $20-40 \mathrm{nM}$ and vehicle was similarly diluted to serve as a control. Stock PKC-I was diluted with vehicle to a concentration of $4 \mu \mathrm{M}$. To obtain solution containing both PKM+PKC-I, the stock PKC-I was diluted with the working solution of PKM to a concentration of $4 \mu \mathrm{M}$ PKC-I, and incubated at $37^{\circ} \mathrm{C}$ for 15 min to inactivate PKM. When using solutions containing PKM, PKC I or vehicle, the recording electrode tip was filled with plain in ternal recording solution, then back-filled with the peptide-containing solution. $\omega$-conotoxin GVIA (Sigma) was dissolved in filtered distilled water (1 mM stock) and $10 \mathrm{ml}$ aliquots were lyophilized and stored at $-20^{\circ} \mathrm{C}$. Just before the experiment $\omega$-conotoxin was reconstituted in external recording solution (see below) to a concentration of 1-10 $\mu \mathrm{M}$. On the day of the experiment nifedipine (Sigma) was dissolved in dimethylsulfoxide (DMSO) to $10 \mathrm{~mm}$, then diluted with external recording solution to $1-10 \mu \mathrm{M}$ and kept covered with aluminum foil to exclude light. All solutions, except the external recording solution, were kept on ice throughout the experiment.

Whole-cell patch-clamp recording techniques. Voltage-clamp recordings were made using the whole-cell variant of the patch-clamp technique (Hamill et al., 1981) with glass recording patch pipettes (Fisher Microhematocrit tubes, Fisher Scientific, Pittsburgh, PA), electrode tip resistances of 1-2 M $\Omega$ and seal resistance greater than $1 \mathrm{G} \Omega$ The external solution contained $5 \mathrm{mM} \mathrm{CaCl}, 67 \mathrm{~mm}$ choline $\mathrm{Cl}, 100 \mathrm{~mm}$ tetraethylammonium chloride, $5.6 \mathrm{~mm}$ glucose, $5.3 \mathrm{~mm} \mathrm{KCL}, 10 \mathrm{~mm}$ Hepes, and $0.8 \mathrm{~mm} \mathrm{Mg}{ }^{2+} \mathrm{Cl}_{2}$ (pH 7.3-7.4, 320-330 mOsm). Recording electrodes were filled with recording solution consisting of $140 \mathrm{mM}$ cesium $\mathrm{Cl}, 10 \mathrm{~mm}$ Hepes, $10 \mathrm{~mm}$ EGTA, $5 \mathrm{~mm} \mathrm{Mg}^{2+}$ ATP and $0.1 \mathrm{~mm}$ $\mathrm{Li}^{+} \mathrm{GTP}$ (all reagents from Sigma). The $\mathrm{pH}$ was adjusted to $7.2-7.3$ with $1 \mathrm{M} \mathrm{CsOH}$ after addition of ATP and GTP, and the final osmolality (280-290) was $10-15 \%$ below that of the external recording solution. Experiments were performed with vehicle diluted in internal recording solution (control) or solutions containing PKM, PKM । PKC-I, or PKC-I alone diluted in recording solution (treated) which were "dialyzed" into the cell following patch rupture. In 10 cells, significant amounts of recording solution containing phenol red dye could be seen to enter 10 cells within 1-3 min of patch rupture, indicating that under the recording conditions used, significant dialysis of electrode contents would likely have occurred within the first $3 \mathrm{~min}$ of recording.

Cells were stimulated with voltage steps generated by the program Cr.AMPFX (DCI.AMP, Axon Instruments, Foster City, CA) and detected using an Axopatch 1B patch-clamp amplifier (Axon Instruments). Initial input resistances were $500 \mathrm{M} \Omega$ to $1.5 \mathrm{G} \Omega$ and series resistance $1-4$ $M \Omega$ Currents were filtered with a Bessel filter at $10 \mathrm{kHz}(-3 \mathrm{~dB})$, stored, and analysed with the program CLAMPAN (Axon Instruments).

Nifedipine and $\omega$-conotoxin GVIA were applied to the cell using pressure injection $(0.5 \mathrm{kPa})$ from blunt-tipped $(10-40 \mu \mathrm{m}$ opening) glass micropipettes positioned approximately $50 \mu \mathrm{m}$ from the cell. The pipettes were lowered into the bath immediately prior to a $2-5 \mathrm{sec}$ application of drug, then after a $2 \mathrm{sec}$ pause following drug application, currents were evoked by depolarization. After $10-30 \mathrm{sec}$, a second application was performed, currents evoked, and the pipette removed from the bath. Application of diluent alone had no effect on the calcium current amplitude
Analysis of current components. At least three calcium current components were present in nodose and DRG neurons (Nowyky et al., 1985; Fox et al., 1987). The T-current was isolated by depolarizing the cell from holding potentials $\left(V_{h}\right)$ of -80 or $-90 \mathrm{mV}$ to command potentials $(V)$ of -60 to $-30 \mathrm{mV}$. Depolarizations more positive than $-30 \mathrm{mV}$ evoked higher threshold current components that activated and inactivated more slowly (N, L, non-N,L). Currents were evoked by depolarization to $V_{c}=0-+10 \mathrm{mV}$ at $1 \mathrm{~min}$ intervals after patch rupture, with the cell alternately held at a $V_{h}$ of $-80 \mathrm{mV}$ and $-40 \mathrm{mV}$. The slowly inactivating current evoked by depolarization to a $V_{c}=0$ to +10 $\mathrm{mV}$ from $V_{b}=-40 \mathrm{mV}$ was used as an estimate of the $\mathrm{L}+$ non-N,L current component, and the additional, more rapidly inactivating current component evoked from $V_{b}=-80 \mathrm{mV}$ as an estimate of the $\mathrm{N}$ current component. Pharmacologic antagonists were also used to determine the relative proportion of current attributable to N-, L-, and non-N,L-type calcium currents, by measuring the percentage of current abolished by the N-type antagonist $\omega$-conotoxin GVIA alone, and with the addition of the L-type antagonist nifedipine. In the presence of both antagonists, the mean residual (non-N,L) current was small, with an amplitude $\sim 25 \%$ of the current amplitude prior to the administration of antagonists. Calibration voltage pulses $\left( \pm 5 \mathrm{mV}\right.$ ) at $V_{t h}=80 \mathrm{mV}$ were obtained on representative cells immediately after patch rupture to normalize the currents for cell capacitance and check for bias in the cell size between control and PKM-treated cells.

Leak current was estimated as the inverse of the current generated by hyperpolarizing commands of equal value to those used to depolarize the cell. These were digitally subtracted from the appropriate inward current to obtain the leak-subtracted calcium current.

Current-voltage (IV) curves were constructed in the following manner. As soon as possible after patch rupture, each cell was depolarized in $10 \mathrm{mV}$ steps increasing from $-30 \mathrm{mV}$ to $+160 \mathrm{mV}$ from a holding potential of $-80 \mathrm{mV}$. This produced command potentials $(V)$ of -110 to $+80 \mathrm{mV}$. Using the CLAMPAN program with the autopeak function set to a three point average, the peak inward current was determined for each current trace, and plotted as a function of $V_{r}$. The baseline was determined by a least-squares fit of the line connecting the points from $-110 \mathrm{mV}$ to $-60 \mathrm{mV}$, and this line was subtracted from the data points at each voltage step. The baseline-subtracted curves were averaged to produce mean \pm SEM values at each voltage step for control and PKM treated cells.

Significance was determined using the two-tailed Student $t$ test and analysis of variance (ANOVA) functions of the InStat program (GRAPH$\mathrm{PAD})$, and defined as a $p$ value $<0.05$.

\section{Results}

$P K M$ enhanced calcium currents in rat dorsal root ganglion neurons

Whole cell voltage-activated calcium currents were elicited in isolated, dissociated DRGs by depolarization to $+10 \mathrm{mV}$ from holding potentials $\left(V_{h}\right)$ of $-80 \mathrm{mV}$ alternating with $-40 \mathrm{mV}$ at 1 min intervals. Currents corresponding to both low threshold voltage-activated (T-type) and high threshold voltage-activated (N-, L-, and non-N,L) (Nowycky et al., 1985; Mintz et al., 1992) were observed. As the T-type currents were present in $<10 \%$ of neurons, analysis was confined to the high threshold voltageactivated currents. In Figure 1, the mean \pm SEM of the peak inward currents elicited from $V_{h}=-80 \mathrm{mV}(A)$, and $V_{h}=-40$ $\mathrm{mV}(B)$ for 39 control cells and 39 cells treated with PKM are plotted against time from patch rupture. Representative high threshold voltage-activated calcium currents recorded in DRGs stimulated by the protocol described above are shown in Figure $1 C$. The left-hand tracing was recorded in a neuron dialyzed with buffer-containing control recording solution, the right-hand tracing from a DRG dialyzed with recording solution containing 20 nM PKM. In both control and PKM-treated neurons, currents evoked from more negative holding potentials $\left(V_{b}=-80 \mathrm{mV}\right.$; solid squares) had larger peak amplitudes than currents evoked from more positive holding potentials $\left(V_{h}=-40 \mathrm{mV}\right.$; open squares).

As can be seen in the plots of $I_{\mathrm{Ca}}$ versus time (Fig. $1 A, B$ ), the 



Figure I. PKM increased peak whole-cell $I_{\mathrm{ca}}$ at both $V_{h}=-80$ and $-40 \mathrm{mV}$. Currents were elicited in isolated rat DRGs by depolarization to a command potential $V_{c}$ of $+10 \mathrm{mV}$ from a holding potentials $V_{h}$ of $-80 \mathrm{mV}$ and $-40 \mathrm{mV}$, alternating at one minute intervals. The average of the peak inward calcium current $\left(-I_{\mathrm{Ca}}\right)$ plotted versus time from patch rupture for $V_{h}=-80 \mathrm{mV}(A)$ or $-40 \mathrm{mV}(B)$ increased to a maximum value between 1 and 5 min, and then progressively decreased for the remainder of the recording. Each point is the mean \pm SEM of 39 individual cells. The mean current at both holding potentials was significantly $\left({ }^{*}, p<0.01 ; *, p<0.05\right.$ ) increased in PKM-treated cells compared to control cells. Representative current tracings $(C)$ at both holding potentials $(-80 \mathrm{mV}$, solid square; $-40 \mathrm{mV}$, open square) elicited by $100 \mathrm{msec}$ depolarizations to $+10 \mathrm{mV}$ are shown for a control cell and a cell dialysed with $20 \mathrm{nM}$ PKM in the recording electrode.

maximum inward currents at both $V_{h}=-80 \mathrm{mV}$ and $-40 \mathrm{mV}$ were larger in the cells treated with PKM (solid circles). The average peak current at both holding potentials increased with time to a maximum between 2 and $5 \mathrm{~min}$, then decreased for the remainder of the recording. Individual cells peaked at different times from patch rupture, thus the peak values shown in Figure 1 for control and PKM-treated cells were lower than the absolute peak currents obtained by averaging the maximum inward current for each cell $\left(V_{h}=-80 \mathrm{mV}\right.$; control $3.84 \pm 0.38$ $\mathrm{nA}$; PKM-treated $5.32 \pm 0.41 \mathrm{nA} ; n=39 ; p<0.005, V_{h}=$ $-40 \mathrm{mV}$ : control $2.69 \pm 0.36 \mathrm{nA}$; PKM-treated $3.74 \pm 0.29$ $\mathrm{nA} ; n=39 ; p<0.01$ ). The average time to reach maximum peak $I_{\mathrm{Ca}}$ was similar in controls and PKM-treated cells at hoth holding potentials. The currents elicited at 1 min post patch rupture were already significantly elevated in PKM-treated cells ( $p$ $<0.01$ ), implying significant leakage of PKM by $1 \mathrm{~min}$. Due to the need to obtain calibration depolarizations and $I V$ curves immediately upon patch rupture, the minimum time interval before the first $90 \mathrm{mV}$ depolarization was at least $40-50 \mathrm{sec}$.

\section{The effect of PKM was antagonized by $P K C$ inhibitor peptide}

PKC inhibitor peptide (PKC-I) (4 $\mu \mathrm{M}$ ) added to the PKM-containing recording solution abolished the enhancement in peak inward $I_{\mathrm{C}}$ seen with PKM alone $\left(V_{h}=-80 \mathrm{mV}\right.$ : $3.06 \pm 0.47$ $\mathrm{nA} ; n=7 ; p<0.01, V_{h}=-40 \mathrm{mV}: 2.18 \pm 0.29 \mathrm{nA} ; n=7$; $p<0.05$ ). After the first $3 \mathrm{~min}$, the currents in the presence of both PKM + PKC-I were smaller than controls and continued to decrease with time. Peak inward high threshold currents in neurons treated with PKC-I alone were similarly decreased conpared to PKM-treated cells $\left(V_{h}=-80 \mathrm{mV}: 2.94 \pm 0.35 \mathrm{nA} ; n\right.$ $=4 ; p<0.01, V_{h}=-40 \mathrm{mV}: 2.21 \pm 0.32 \mathrm{nA} ; n=4 ; p<$ 0.05 ).
The rate of calcium current rundown was significantly increased by PKC-I

Rundown of current with time was seen in both control and PKM-treated cells (Fig. 1), and appeared to be more rapid in cells treated with PKM compared to control cells. In individual experiments, however, peak currents occured at different times from patch rupture, and thus the rundown portions of the current vs time curves did not coincide. In addition we noted that cells with larger currents (whether control or PKM-treated) tended to run down more quickly than those with smaller currents. To remove these potential sources of bias we nonmalized the rundown portion of the curve for each cell as a percentage of the peak current attained by that cell. For each experiment, currents evoked by depolarizations in the rundown period following the maximum observed current were normalized to the maximum current and plotted versus time for both $V_{h}=-80 \mathrm{mV}$ (Fig. $2 A$ ) and $-40 \mathrm{mV}$ (Fig. 2B).

The PKM-treated cells demonstrated a small, nonsignificant trend towards less rundown of normalized current with time compared to control cells. Cells treated with PKM+PKC-I had significantly increased rundown compared to controls and PKMtreated cells. In neurons treated with PKC-I alone $(n=4)$, the rundown rate was not significantly different from that seen in the presence of both PKM+PKC-I. These results, that is, little incremental effect of additional PKM, and a significant effect of PKC-I, both alone and with PKM, suggested a relatively high level of endogenous PKC activity may have been present in these cells.

\section{PKM did not change the peak current-voltage (IV) relationship}

In frog sympathetic neurons, activation of $\mathrm{PKC}$ by 12,13-phorbol dibutyrate (PDBu) caused a slight shift in the voltage-de- 

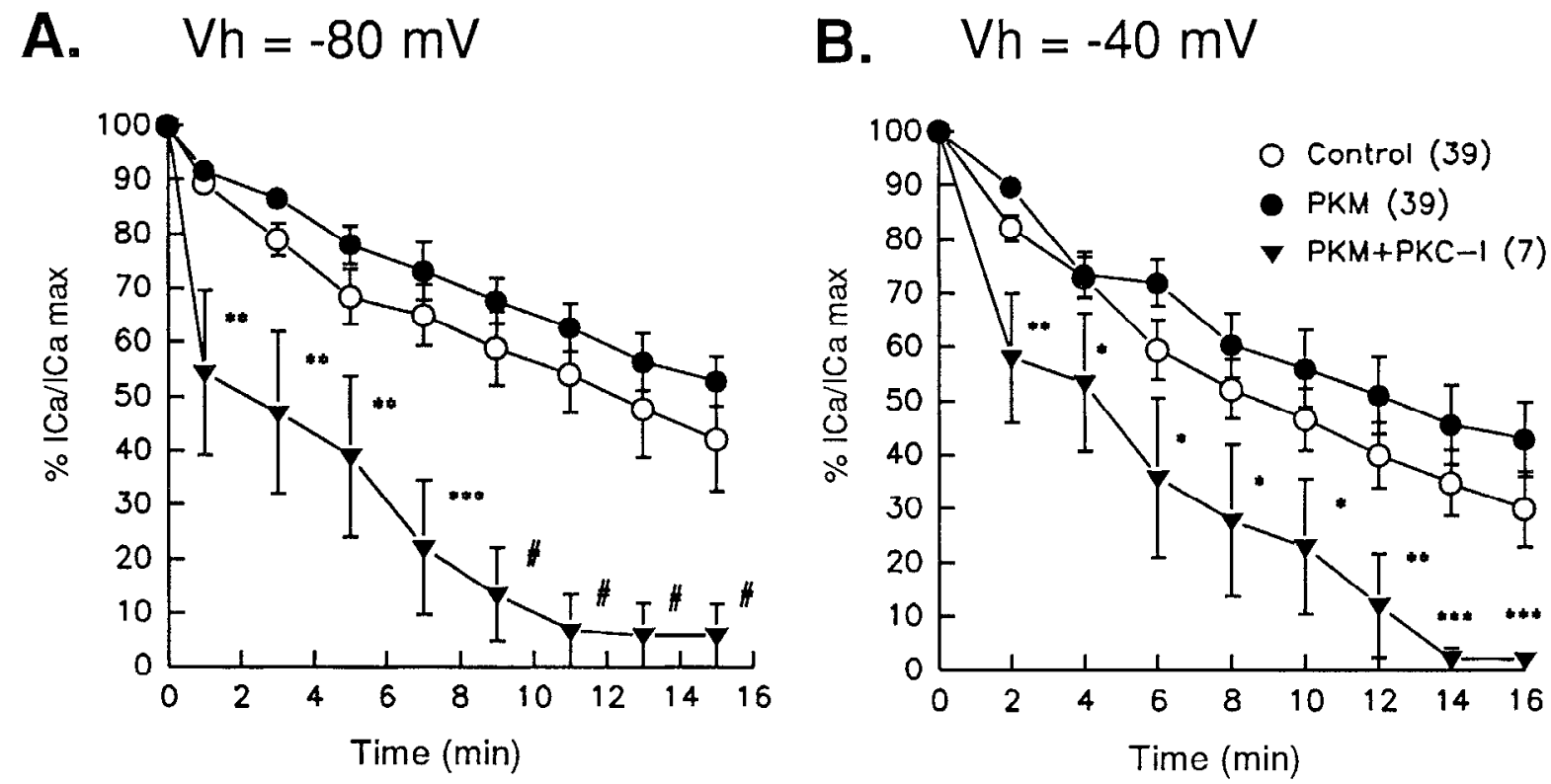

Figure 2. Addition of PKC-I significantly increased the rate of current rundown. Rates of current rundown in control and PKM-treated cells were compared by dividing inward currents $\left(-I_{C_{0}}\right)$ at each time point by the maximum inward current $\left(-I_{C}\right.$ max) attained during the experiment. The rundown period was defined as the period following the maximum $I_{\mathrm{Ca}}$ for each cell. There was no significant difference in the rate of rundown of calcium currents in control versus PKM-treated neurons at either $V_{h}=-80 \mathrm{mV}(A)$ or $V_{h}=-40 \mathrm{mV}(B)$. Addition of PKC-I caused a significant increase in rundown compared to control or PKM-treated cells (\# $p<0.001$; ***, $p<0.005$; ** $p<0.01$;,$p<0.05$, ANOVA). Each value is the mean \pm SEM of $(n)$ cells.

pendence of the $I V$ relationship to more negative potentials (Yang and Tsien, 1993). Figure 3 shows the current-voltage relationship for control (open circles) and PKM-treated neurons (solid circles).

The individual $I V$ curves recorded in control and PKM-treated neurons were baseline-subtracted, then averaged as described in the Materials and Methods section. The maximum mean inward

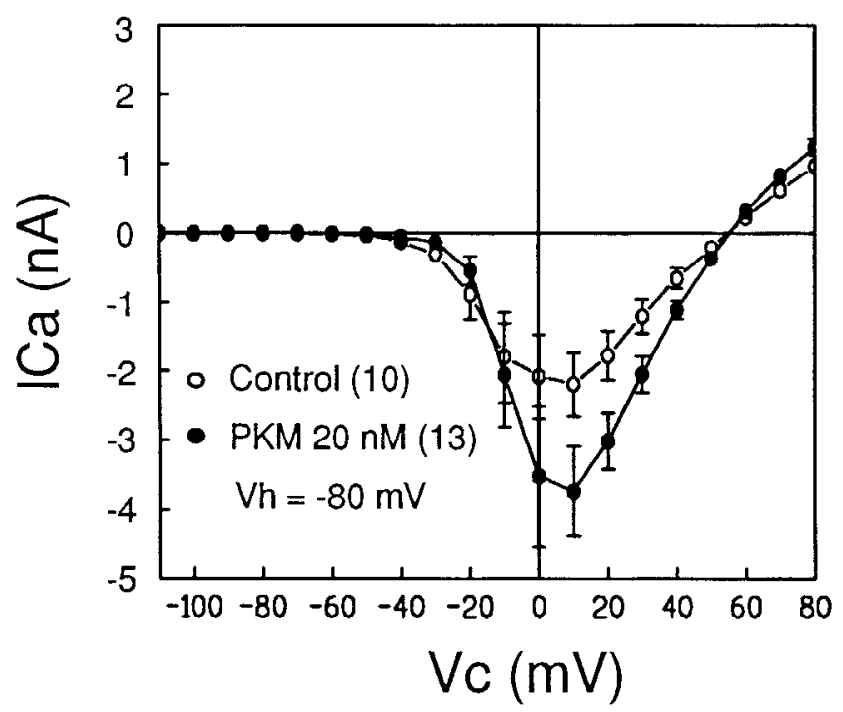

Figure 3. PKM did not shift the calcium current-voltage curve. $I / V$ curves were generated in 10 control (open circles) and 13 PKM-treated neurons (solid circles) by depolarizing the cell from $V_{h}=-80 \mathrm{mV}$ in progressive $100 \mathrm{msec}$ steps from $V_{r}=-110$ to $+80 \mathrm{mV}$. Individual curves were baseline-subtracted and averaged to obtain the mean \pm SEM at each $V_{c}$, as described in the methods section. PKM treatment significantly $(p<0.05)$ increased the amplitude of the maximum mean inward current, but did not alter the voltage dependence of the location of the peak $(+10 \mathrm{mV})$. current was significantly $(p<0.05)$ larger in PKM-treated neurons; however, there was no significant shift in the voltage dependence of the peak current, which occurred at $+10 \mathrm{mV}$ in both control and PKM-treated cells. Thus the increase in whole cell high-threshold calcium currents observed with PKM treatment in this preparation cannot be explained by a shift in the voltage dependence of the $I V$ relationship in PKM-treated cells.

\section{PKM enhanced $N$ - and L-type calcium currents}

We proceeded to test the effect of $\mathrm{N}$ and L-type calcium channel blockers on the enhancement of $I_{\mathrm{Ca}}$ evoked from $-80 \mathrm{mV}$ observed in PKM-treated cells. In Figure 4, the results of a representative experiment in a DRG neuron in which PKM was present in the recording electrode $(A)$ and the corresponding current traces $(B)$ obtained at the time points (1) predrug, (2) post$\omega$-conotoxin GVIA ( $\omega$-CgTX) $10 \mu \mathrm{M}$, and (3) post- $\omega$-CgTX 10 $\mu \mathrm{M}+$ nifedipine $3 \mu \mathrm{M}$ are shown.

In the experiment shown in Figure $4 A$, a DRG neuron dialyzed with PKM was held at $-80 \mathrm{mV}$ and currents were elicited by depolarization to $+10 \mathrm{mV}$. Two applications of $\omega$-CgTX were given 1 min apart at the times marked by the arrows. There was little incremental effect of the second application, indicating that the block by both anatgonists was essentially complete. No recovery from the effect of $(1)-C g T X$ was nhserved; however following application of $3 \mu \mathrm{M}$ nifedipine, partial recovery of peak inward current amplitude was noted. This was consistent with the action of nifedipine (a reversible L-channel antagonist). Little or no recovery of current amplitude was observed in the presence of higher concentrations of nifedipine $(10 \mu \mathrm{M})$. The values for the average peak $I_{\mathrm{Ca}}$ in the presence of (1) no drug (predrug), (2) $\omega$-CgTX $10 \mu \mathrm{M}$, or (3) $\omega$-CgTX $10 \mu \mathrm{M}+$ nifedipine $10 \mu \mathrm{M}$ are graphed in Figure $4 C$. Prior to drug application the average peak current recorded from control cells was $3.7 \pm$ $0.3 \mathrm{nA}$ and that of PKM-treated cells was $5.5 \pm 0.4 \mathrm{nA}(p<$ 

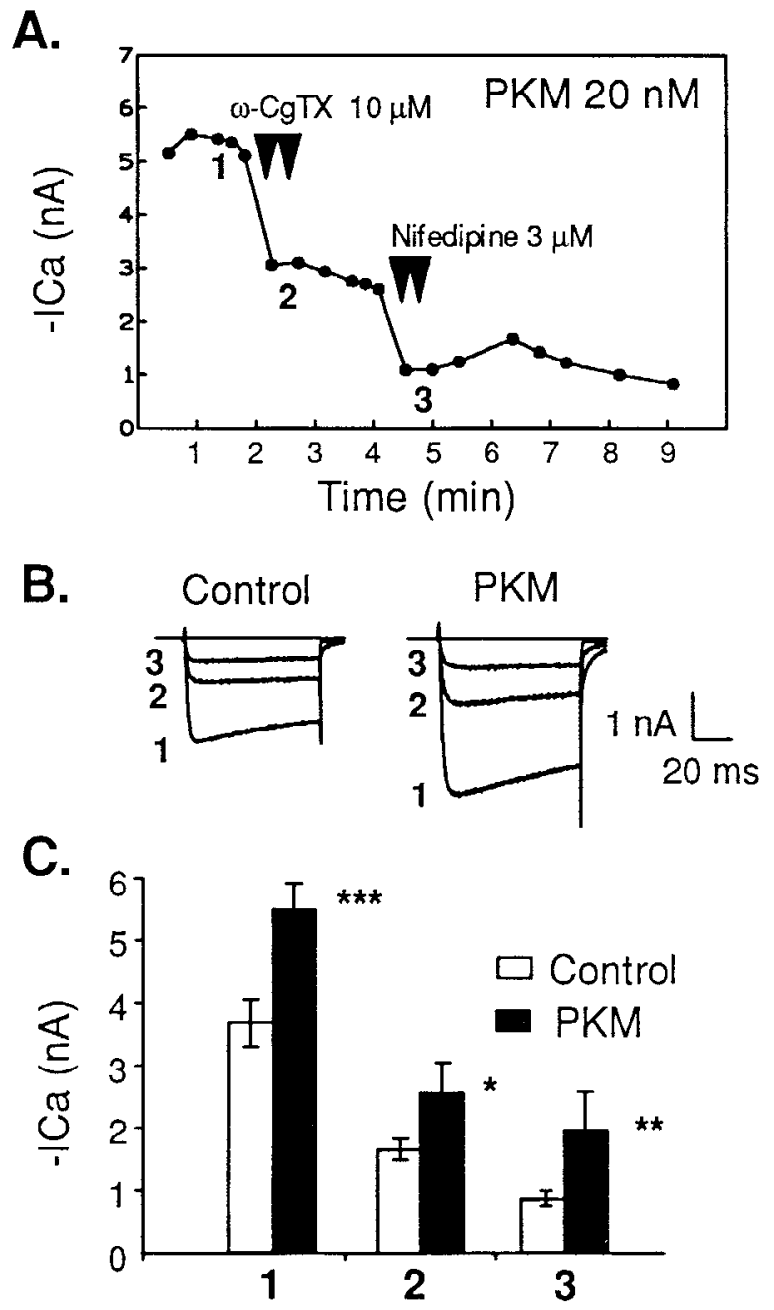

Figure 4. PKM enhanced N, L, and non-N,L current components. In $A$, inward currents elicited in a PKM-treated neuron by depolarization from $V_{h}=-80 \mathrm{mV}$ to $V_{c}=+10 \mathrm{mV}$ are plotted versus time from patch rupture. After the maximum calcium current was observed, two applications of the N-type channel antagonist $\omega$-conotoxin GVIA ( $\omega$ CgTX, $10 \mathrm{mM}$ ) were administered from a pipette placed close to the cell. Following each application, currents were elicited. After the second application the drug pipette was withdrawn from the bath. The predrug current amplitude (1) was decreased by the first application of $\omega$-CgTX (2), and the second application had little additional effect. Currents were elicited for $2 \mathrm{~min}$, then $3 \mathrm{~mm}$ nifedipine was applied in a similar manner from a separate pipelte. Nifedipine caused a further decrease (3) in current amplitude, following which partial recovery was observed. In $B$ representative current tracings from a control and a PKM-treated neuron corresponding to the experimental time points 1,2 , and 3 above are shown. $C$ summarizes the experimental results. When compared with control cells, cells dialyzed with PKM had significantly increased peak currents prior to drug administration ( $I, n=16$ (control), 22 $(\mathrm{PKM}) ; * * *, p<0.005)$, following $\omega-\mathrm{CgTX} 10 \mathrm{~mm}(2, n=16$ (control), 22 (PKM); *, p<0.05), and following nifedipine $10 \mathrm{~mm}(3, n$ $=15$ (control), $16(\mathrm{PKM}) ; *, p<0.01)$. Each bar is the mean $\pm \mathrm{SEM}$.

0.005 ). In the presence of the $\mathrm{N}$-type channel antagonist ( $\omega$ CgTX), the average peak current was reduced by $54 \%$ in control cells $(1.7 \pm 0.2 \mathrm{nA})$ and by $53 \%$ in PKM-treated cells $(2.6 \pm$ $0.5 \mathrm{nA})$. Cells treated with PKM still demonstrated a significantly $(p<0.05)$ increased peak $I_{\mathrm{Ca}}$ compared to controls. In the presence of both $\omega$-CgTX and nifedipine, peak $I_{\mathrm{Ca}}$ decreased by $76 \%$ in control cells $(0.9 \pm 0.1 \mathrm{nA})$, and by $67 \%$ in PKMtreated cells $(1.8 \pm 0.4 \mathrm{nA})$, with a significantly higher $(p<$ 0.01 ) current observed in PKM-treated cells compared to con-
Table 1. Percentage of current attributable to $\mathrm{N}-$, $\mathrm{L}-$, and non$\mathbf{N}, \mathbf{L}$ currents

\begin{tabular}{llll} 
& $\mathrm{N}$ & $\mathrm{L}$ & Non-N,L \\
\hline Control & $54 \pm 3 \%$ & $22 \pm 3 \%$ & $24 \pm 4 \%$ \\
PKM-treated & $53 \pm 3 \%$ & $15 \pm 3 \%$ & $33 \pm 4 \%$
\end{tabular}

The portions of the predrug current in control and PKM-treated cells attributable to N, L, and non-N,L components were calculated as described in the Results, and are expressed as a percentage \pm SEM of the predrug current. There was no significant difference between control and PKM-treated cells in the proportions of the three current components when tested by ANOVA.

trols. By subtracting the current remaining in the presence of $\omega-\mathrm{CgTX}$ from the predrug current (no drug), an estimate of the portion of current attributable to $\mathrm{N}$ in both control $(2.0 \mathrm{nA})$ and PKM-treated cells (2.9 nA) was determined. Similarly, an estimate of $\mathrm{N}+\mathrm{L}$ was calculated by subtracting the current remaining in the presence of both $\omega-\mathrm{CgTX}+$ nifedipine from the pre-drug current for control $(2.8 \mathrm{nA})$ and PKM-treated cells (3.7 nA). Finally an estimate of the portion of current attributable to $\mathrm{L}$ was calculated by subtracting the value for $\mathrm{N}$ calculated above from the value for $\mathrm{N}+\mathrm{L}$ (control: $0.8 \mathrm{nA}$, PKM-treated: 0.8 $\mathrm{nA}$ ). The small residual current remaining in the presence of $\omega$-CgTX and nifedipine was termed the non-N,L component (control: $0.9 \pm 0.1 \mathrm{nA}$, PKM-treated: $1.8 \pm 0.4 \mathrm{nA}$ ). The three components ( $\mathrm{N}, \mathrm{L}$, and non-N,L) were converted to percentages of the total predrug current (no drug) (Table 1).

Using the ANOVA test, there was no significant difference between control and PKM-treated cells in the percentage of current attributable to the $\mathrm{N}, \mathrm{L}$, and non-N,L components, implying that the increase in calcium currents observed with PKM treatment affected all three current groups (N, L, and non-N,L).

\section{Discussion}

PKM enhanced whole cell calcium currents in rat DRGs

We demonstrated that a constitutively active form of $\mathrm{PKC}$ (PKM), when dialyzed into the cell via the recording pipette, increased peak high voltage-activated calcium currents in acutely dissociated rat primary afferent ganglion neurons. These experiments suggested that the net action of PKC on voltage-dependent calcium channels in this preparation was enhancement.

Our data obtained in the presence of calcium channel blockers indicate that PKM appeared to increase both $\mathrm{N}$ - and L-type currents (Braha et al., 1993; Yang and Tsien, 1993), and in addition, affected a residual (non-N,L) calcium current that was relatively slowly inactivating. Several high voltage-activated currents ( $P$, $Q$, and others) with activation and inactivation ranges that overlap those of the $\mathrm{N}$ - and L-type currents have been described recently (Llinas et al., 1989; Mintz et al., 1992; Ellinor et al., 1993; Randall et al., 1993), and the non-N,L component of the calcium current observed in this study is likely comprised of one or more of these additional high voltage-activated calcium currents. Use of specific antagonists that block these additional currents (Aga IVa; P-type, $\omega$-conotoxin MVIIC; Q-type), may identify other calcium currents enhanced by PKM administration.

There appeared to be a high endogenous level of PKC activity in this preparation. PKM treatment did not alter the rate of current rundown compared to control neurons. Dialysis with either PKM + PKC-I-containing solution, or recording solution containing only $\mathrm{PKC}-\mathrm{I}$ significantly increased the current rundown rate compared to control and PKM-treated neurons. The concentra- 
tion of PKC-I administered was greatly in excess of the PKM concentration. Thus, additional PKC activity in the form of PKM did not substantially affect rundown, however inhibition of exogenous PKM and endogenous PKC by a large excess of PKC-I resulted in a significant increase in rundown. Whether the high endogenous PKC activity inferred from these experiments was a result of the dissociation process, or a normal feature of DRG neurons is not known. Progressively increasing PKC activity over several days has been observed in neuronal cultures (Burgess et al., 1986) and in acutely dissociated superior cervical ganglion neurons after prior removal of central inputs in vivo (Roivainen, 1991), suggesting that increased PKC activation may be a physiological response to denervation and/or dissociation. Increased PKC activity has been implicated as a pathogenic factor in some models of neuronal death (Manev et al., 1989; Hara et al., 1990; Mattson, 1991; Candeo et al., 1992), in plying that elevated PKC activily could be pathologic in these systems.

Experiments using phorbol esters to activate endogenous PKC have demonstrated some variability in the reported effects. Phorbol esters increase peak calcium currents in sensory neurons from rat and other species (Swartz, 1993; Swartz et al., 1993; Yang and Tsien, 1993). However, phorbol esters have also been reported to decrease calcium currents (Rane and Dunlap, 1986; Gross and Macdonald, 1989; Rane et al., 1989; Boland et al., 1991). There are several possible explanations for this discrepancy. Phorbol esters activate PKC by binding to the cytosolic (inactive) form of $\mathrm{PKC}$, and therefore, variations in endogenous cytosoiic PKC levels could influence the magnitude of the effect of phorbol esters on calcium currents. Secondly, the activation process for $\mathrm{PKC}$ requires translocation of the activated molecule to the plasma membrane (or other site of action), and differences in translocation of isoforms of PKC have been described (Kruger et al., 1991). Thus, variations in the effects of indirect activators of PKC might be due to precxisting variations in endogenous PKC content, activation, or translocation, as well as differences in the action of PKC at its target. Attenuation of PKC levels in response to phorbol ester administration has been reported (Rodriguez-Pena and Rozengurt, 1984; Wolf et al., 1984). In addition, there is evidence that phorbol esters may directly inhibit calcium channel function (Hockberger et al., 1989; Doerner et al., 1990), and thus their actions on the calcium channel may not be mediated solely by alterations in PKC activity.

\section{Putative mechanisms of action of PKM}

PKM may be Inodulating calcium channel activity by phosphorylation of one or more channel subunits. There are several consensus phosphorylation sites for PKC on the cloned $\alpha 1$ (Dubel et al., 1992) and $\beta$ (Hullin et al., 1992) subunits of the L-type calcium channel, and PKC can phosphorylate these sites in vitro (Jahn et al., 1988; Ahlijanian et al., 1991). The PKM preparation used in this study has been shown to phosphorylate a known consensus site on the a subunit of the $\gamma$-amminobutyric acid $A$ receptor $\left(\mathrm{GABA}_{\mathrm{A}}\right)$ (Browning et al., 1990). Another possibility is that PKM may modulate calcium channel function indirectly by phosphorylation of other structures associated with calcium channels, such as $G$ proteins. Inhibitory $G$ proteins have been implicated as a second messenger system involved in the modulation of calcium currents by various receptor agonists (Gross et al., 1990; Swartz, 1993); however, using GTP analogs, Yang and Tsien (1993) did not find evidence for $G$ protein involve- ment in the effects of the phorbol ester PDBu on frog sympathetic ganglion calcium currents.

The increase in calcium current seen in the PKM-treated cells could be explained by an increase in either channel number, conductance or open time. It is possible that the observed effect of acute PKM treatment on calcium current was due to an increased total number of calcium channels. This alteration would have to occur within the first few minutes of application, since currents in cells treated with PKM were higher than controls within the first minute of administration. This could occur as a result of addition of new channels into the membrane, or by recruitment of previously inactive calcium channels, as has been described in Aplysia (DeRiemer et al., 1985; Strong et al., 1987). Our results suggest that such alterations in channel number would have to involve N, L, and additional high-threshold voltage-activated calcium channels. Although the present experiments cannot determine whether alterations in the underlying channel properties were responsible for the increased whole-cell calcium current caused hy PKM, we can speculate that increased calcium channel conductance, open time and/or opening frequency might play a part. Our current-voltage curves indicate that whole cell conductance was likely increased, without a significant shift in the voltage range of activation. Indirect activation of PKC by phorbol esters has been shown to increase $\mathrm{N}$ and L channel opening probability (Yang and Tsien, 1993). Based on single channel data, several investigators have postulated that calcium channels may reside in different modes that are more or less excitable (Boland and Bean, 1993; Delcour et al., 1993), and that the action of PKC is to switch the cell to a more easily excited mode (Yang and Tsien, 1993). Whether differences in underlying $G$ protein activity determine the modal status is presently a subject of debate (Boland and Bean, 1993).

In addition to the actions of $\mathrm{PKC}$, the phosphorylation status of calcium channels may be independently modulated by other kinases, such as cAMP-dependent protein kinase (PKA, Gross et al., 1990b; Ahlijanian et al., 1991; Diverse-Pierluissi and Dunlap, 1993), and by endogenous phosphatases. Inhibition of endogenous phosphatases would prolong the phosphorylated state, and possibly increase calcium currents.

In summary we have observed that constitutively active PKC (PKM) increased voltage-activitated calcium currents in rat dorsal root ganglion neurons. This effect was in contrast to the reported effects of some phorbol esters to reduce calcium currents, and implies that some of the effects of phorbol esters, notably calcium current inhibition, may involve mechanisms other than, or in addition to activation of endogenous PKC. The mechanism by which PKM enhances calcium currents in this preparation is not yet clear; however a shift in the voltage dependence of the current-voltage relationship does not appear to be involved.

\section{References}

Ahlijanian MK, Striessnig J, Catterall WA (1991) Phosphorylation of an $\alpha$ l-like subunit of an $\omega$-conotoxin-sensitive brain calcium channel by cAMP-dependent protein kinase and protein kinase C. J Biol Chem 266:20192-20197.

Alkon DL, Rasmussen H (1988) A spatial-temporal model of cell activation. Science 239:998-1005.

Boland I, Bean BP (1993) Modulation of N-type calcium channels in bullfrog sympathetic neurons by luteinizing hormone-releasing hormone: kinetics and voltage dependence. J Neurosci 13:516-533.

Boland L, Allen $\Lambda \mathrm{C}$, Dingledine $\mathbf{R}$ (1991) Inhibition by bradykinin of voltage-activated barium current in a rat dorsal root ganglion cell line: role of protein kinase C. J Neurosci 11:1140-1149. 
Braha O, Edmonds B, Sacktor T, Kandel ER, Klein M (1993) The contributions of protein kinase $\mathrm{A}$ and protein kinase $\mathrm{C}$ to the actions of 5-HT on the L-type Ca ${ }^{2+}$ current of the sensory neurons in Aplysia. J Nenrosci 13:1839-1851.

Browning MD, Bureau M, Dudeck EM, Olsen RW (1990) Protein kinase $\mathrm{C}$ and cAMP-dependent protein kinase phosphorylate the a subunit of the purified $\gamma$-aminobutyric acid A receptor. Proc Natl Acad Sci USA 87:1315-1318.

Burgess SK, Sahyoun N, Blanchard SG, LeVine H, Chang KJ (1986) Phorbol ester receptors and protein kinase $\mathrm{C}$ in primary neuronal cultures: development and stimulation of endogenous phosphorylation. J Cell Biol 102:312-319.

Candeo P, Favaron M, Lengyel I, Manev RM, Rimland JM, Manev H (1992) Pathological phosphorylation causes neuronal death: effect of okadaic acid in primary culture of cerebellar granule cells. J Neurochem 59:1558-1561.

Chang CF, Gutierrez LM, Mundina-Weilenmann C, Hosey MM (1991) Dihydropyridine sensitive calcium channels from skeletal muscle. II. Functional effects of differential phosphorylation of channel subunits. J Biol Chem 266:16395-16400.

Delcour AH, Lipscombe D, Tsien RW (1993) Multiple modes of Ntype calcium channel activity distinguished by differences in gating kinetics. J Neurosci 13:181-194.

DeRiemer SA, Strong JA, Albert KA, Greengard P, Kaczmarek LK (1985) Enhancement of calcium current in Aplysia neurones by phorbol ester and protein kinase C. Nature 313:313-316.

Diverse-Pierluissi M, Dunlap K (1993) Distinct, convergent second messenger pathways modulate neuronal calcium currents. Neuron 10: $753-760$.

Doerner D, Pitler TA, Alger BE (1988) Protein kinase C activators -block specific calcium and potassium current components in isolated hippocantupal neurons. J Neurosci 8:4069-4078.

Doerner D, Abdel-Latif M, Rogers TB, Alger BE (1990) Protein kinase C-dependent and independent effects of phorbol esters on hippocampal calcium channel current. J Neurosci 10:1699-1706.

Dubel SJ, Starr TV, Hell J, Ahlijanian MK, Enyeart JJ, Catterall WA, Snutch TP (1992) Molecular coning of the $\alpha 1$ subunit of an $\omega$-conotoxin-sensitive calcium channel. Proc Natl Acad Sci USA 89:50585062 .

Ellinor P, Zhang J-F, Randall AD, Zhou M, Swartz TL, Tsien RW, Horne WA (1993) Functional expression of a rapidly inactivating neuronal calcium channel. Nature 363:455-458.

Ewald DA, Mathies IIJ, Perney TM, Walker MW, Miller RJ (1988) The effect of down regulation of protein kinase $\mathrm{C}$ on the inhibitory modulation of dorsal root ganglion neuron $\mathrm{Ca}^{2+}$ currents by neuropeptide Y. J Neurosci 8:2447-2451.

Fox AP, Nowycky MC, Tsien RW (1987) Kinetic and pharmacological properties distinguishing three types of calcium currents in chick sensory neurons. J Physiol (Lond) 394:147-172.

Gross RA, Macdonald RL (1989) Activators of protein kinase C selectively enhance inactivation of a calcium current component of cultured sensory neurons in a pertussis toxin-sensitive manner. J Neurophys 61:1259-1269.

Gross RA, Wilcy JW, Ryan-Jastrow T, Macdonald RL (1990a) Regulation by GTP and its stable thiol derivatives of calcium current components in rat nodose ganglion neurons. J Mol Pharmacol 37:546553.

Gross RA, Moises HC, Uhler MD, Macdonald RL (1990b) Dynorphin $\mathrm{A}$ and $\mathrm{c}$-AMP-dependent protein kinase independently regulate neuronal calcium current. Proc Natl Acad Sci USA 87:7025-7029.

Hamill OP, Marty A, Neher E, Sakmann B, Sigworth FJ (1981) Improved patch-clamp techniques for high-resolution current recording from cells and cell-free membrane patches. Pfluegers Arch 391:85100.

Hara H, Onodera H, Yoshidomi M, Matsuda Y, Kogure K (1990) Staurosporine, a novel protein kinase $\mathrm{C}$ inhibitor, prevents post-ischemic neuronal damage in the gerbil and rat. J Cereb Blood Flow Metab 10:646-653

Hockberger P, Toselli M, Swandulla D, Lux HD (1989) A diacylglcerol analogue reduces neuronal calcium currents independently of protein kinase C activation. Nature 338:340-342.

Huang KP, Huang FL (1986) Conversion of protein kinase C from a $\mathrm{Ca}^{2+}$-dependent to an independent form of phorbol ester-binding protein. Biochem Biophys Res Commun 139:320-326.

Hullin R, Singer-Lahat D, Freichel M, Biel M, Dascal N, Hofman F,
Flockerzi V (1992) Calcium channel $\beta$ subunit heterogeneity: functional expression of cloned cDNA from heart, aorta and brain. EMBO J 11:885-890.

Jahn H, Nastainczyk W, Rohrkasten A, Schneider T, Hofman F (1988) Site-specific phosphorylation of the purified receptor for calcium channel blockers by cAMP- and cGMP-dependent protein kinases, protein kinase C, calmodulin-dependent protein kinase II anıl casein kinase II. Eur J Biochem 178:535-542.

Kruger KE, Sossin WS, Sacktor TC, Bergold PJ, Beushaussen S, Schwartz JH (1991) Cloning and characterization of $\mathrm{Ca}^{2+}$-dependent and $\mathrm{Ca}^{2+}$-independent PKCs expressed in Aplysia sensory cells. J Neurosci 11:2303-2313.

Lacerda AE, Rampe D, Brown AM (1988) Effects of protein kinase C activators on cardiac calcium channels. Nature 335:249-251.

Liu Q Y, Karpinski E, Pang PK (1993) Comparison of the action of two protein kinase $\mathrm{C}$ activators on dihydropyridine-sensitive $\mathrm{Ca}^{2+}$ channels in neonatal rat ventricular myocytes. Biochem Biophys Res Commun 191:796-801

Llinas R, Sugimori M, Lin JW, Cherksey B (1989) Blocking and isolation of a calcium channel from neurons in mammals and cephalopods utilizing a toxin fraction (FTX) from funnel-web spider poison. Proc Natl Acad Sci USA 86:1689-1693.

Madison DV (1989) Phorbol esters increase unitary calcium channel activity in cultured hippocampal neurons. Soc Neurosci Abstr 15:16.

Manev H, Favaron M, Guidotti A, Costa E (1989) Delayed increase of $\mathrm{Ca}^{2+}$ influx elicited by glutamate: role in neuronal death. Mol Pharmacol 36:106-112.

Mathie A, Bernheim L, Hille B (1992) Inhibition of N- and L-type calcium channels by muscarinic receptor activation in rat sympathetic neurons. Neuron 8:907-914.

Mathies HJ, Palfrey HC, Hirning LD, Miller RJ (1987) Down regulation of protein kinase $\mathrm{C}$ in neuronal cells: effects on neurotransmitter release. J Neurosci 7:1198-1206.

Mattson MP (1991) Evidence for the involvement of protein kinase C. in neurodegenerative changes in cultured human cortical neurons. Exp Neurol 112:95-103.

Mintz IM, Venema VJ, Swiderek KM, Lee TD, Bean BP, Adams ME (1992) P-type calcium channels blocked by the spider toxin $\omega$-Aga IV A. Nature 355:827-829.

Nowycky MC, Fox AP, 'Isien RW (1985) 'I 'hree types of neuronal calcium channels with different calcium agonist sensitivity. Nature 316:440-443.

O'Dell TJ, Alger BE (1991) Single calcium channels in rat and guineapig hippocampal neurons. J Physiol (Lond) 436:739-767.

Randall AD, Wendland B, Schweizer F, Miljanich G, Adams ME, Tsien RW (1993) Five pharmacologically distinct high voltage-activated $\mathrm{Ca}^{2+}$ channels in cerebellar granule cells. Soc Neurosci Abstr 19: 1478.

Rane SA, Dunlap K (1986) Kinase C activator 1,2-oleoylacetylglycerol attenuates voltage-dependent calcium current in sensory neurons. Proc Natl Acad Sci USA 83:184-188.

Rane SA, Walsh MP, MacDonald JR, Dunlap K (1989) Specific inhibitors of protein kinase $\mathrm{C}$ block transmitter-induced modulation of sensory neuron calcium current. Neuron 3:239-245.

Rodriguez-Pena A, Rozengurt E (1984) Disappearance of $\mathrm{Ca}^{2+}$-sensitive, phospholipid-dependent protein kinase activity in phorbol estertreated 3T3 cells. Biochem Biophys Res Commun 120:1053-1059.

Roivainen $R$ (1991) Increase in protein kinase C-b-like immunoreactivity in the rat superior cervical ganglion after decentralization. Neurosci Res 11:292-296.

Strong JA, Fox AP, Tsien RW, Kaczmarek LK (1987) Stimulation of protein kinase $\mathrm{C}$ recruits covert calcium channels in Aplysia bag cell neurons. Nature 325:714-717.

Swartz KJ (1993) Modulation of $\mathrm{Ca}^{2+}$ channels by protein kinase $\mathrm{C}$ in rat central and peripheral neurons: disruption of $\mathrm{G}$ protein-mediated inhibition. Neuron 11:305-320.

Swartz KJ, Merritt $\Lambda$, Bean BP, Lovinger DM (1993) Protein kinase C modulates glutamate receptor inhibition of $\mathrm{Ca}^{2+}$ channels and synaptic transmission. Nature 361:165-168.

Tanaka C, Sato N (1992) Localization of subspecies of protein kinase $C$ in the mammalian nervous system. Neurochem Int 21:499-512.

Wolf M, Sahyoun N, LeVine H III, Cuatrecasas P (1984) Protein kinase C: rapid enzyme purification and substrate-dependence of the diacylglycerol effect. Biochem Biophys Res Commun 122:1268-1275. 
Woodgett JR, Hunter T (1987) Isolation and characterization of two distinct forms of protein kinase C. J Biol Chem 262:4836-4843.

Yang J, Tsien RW (1993) Enhancement of N- and L-type calcium channel currents by protein kinase $\mathrm{C}$ in frog sympathetic neurons. Neuron 10:127-136.
Zhang J-F, Randell AD, Ellinor PT, Horne WA, Sather WS, Tanabe T, Schwartz TL, Tsien RW (1993) Distinctive pharmacology and kinetics of cloned neuronal $\mathrm{Ca}^{2+}$ channels and their possible counterparts in mammalian CNS neurons. Neuropharmacology 32:10751088. 